\title{
Canadian Educational Development Centre Websites: More Ebb Than Flow?
}

\author{
Nicola Simmons ${ }^{1}$ \\ University of Waterloo
}

This paper examines information portrayed on Canadian educational development (ED) centre websites and, in particular, whether information that corresponds to questions compiled from a literature search of ED centre practices is readily available from centre websites. This study phase is part of a larger national study of Canadian educational development centres' practices.

\section{The Seascape: An Overview}

$\mathrm{R}$ esearchers in the UK (Gosling, 2001, 2006) and US (Lewis, 1996) have outlined the historical growth of faculty development. Elrick (1990) discussed conditions that led to Canadian educational development (ED) initiatives; Donald (1986), Wilcox (1997), and Scarfe (2004) chronicled the history of Canadian ED centre growth; and Mindorff, Ratkovic, and Babady-Bila (2004) mapped the activities of 42 centres across Canada. However, there is limited literature available on the practices of Canadian ED units.

The Educational Developers Caucus (EDC) ED Profiler (2004-2005) is now significantly out of date. While the Society for Teaching and Learning in Higher Education (STLHE) website (www.stlhe. ca/en/links/teaching_centre.php) lists 34 Canadian teaching centres, only links to ED centres are provided; there is no database for information comparison. In addition, there are more than 63 centres at postsecondary institutions in Canada. A complete list that includes colleges is available through the University of Waterloo at www.uwaterloo.ca/canu/index. php, but this provides links to institutions rather than educational development centres. Kreber and Brook's (2001) assertion that there remains a need to map the current Canadian landscape of ED centres

\footnotetext{
${ }^{1}$ Many thanks to the Educational Developers Caucus for funding to support this work. I also owe debts of thanks to the following colleagues who, while not involved in writing this article, contributed to the literature review and data collection and have been instrumental in moving the project forward: Alice Cassidy, Martha Crealock, Chris Groeneboer, Erika Kustra, Jolyn Lee, Alice Macpherson, Michael Potter, Ruth Rodgers, Anne Scrimger, Margaret Wilson, and Janet Z-K Wolstenholme.
} 
and their practices holds true. Accordingly, our collaborative national study set out to describe the practices of Canadian post-secondary (university and college) ED centres, with the intention of gathering and compiling sharable information to be made available on the EDC website.

In turning to centre websites to compile some of this data, certain trends became apparent about what we communicate on our websites and perhaps more importantly, what we do not. The purpose of this paper is therefore to discuss those trends and what falls "between the tides." In it, I discuss the nature and purpose of ED websites as communication tools: What are we communicating, to whom, and for what purpose?

\section{Currents: Background to the Study Questions}

While this paper outlines the kinds of information that are available on ED websites, some background on how the study questions were compiled may be useful. David Gosling (UK), who has been collecting information on ED centres internationally, was a useful initial contact; his helpful summaries provided a strong starting point for questions to guide the data collection. In addition, the research team compiled a summary of relevant literature, particularly Canadian sources. We used an online platform (Sharepoint) for our discussion as we developed our list of questions from this body of work. The resulting 39 data collection questions (see Table 1) were developed from Carusetta and Cranton, 2005; Cox, 2002; Gosling, 2001, 2006; Konrad, 1983; Kreaden, 2001; Lawlor and King, 2003; Scarfe, 2004; and Wilcox, 1997, 1998.

\section{Floating on the Sea: Data Collection}

Initially we compiled data from our own centres in response to the question list. This pilot phase allowed us to assess our original list of questions, and it was clear that 39 questions would prove an onerous list for any centre to address. In addition, we found some overlap and a need for further clarity before we could reasonably ask others to contribute to the database.

We asked our research assistant to chart our initial responses and look at the data we had already compiled and confirm which of it was available through the centre websites. While we knew it was unlikely that all 39 questions could be answered online, and that our next step (currently in progress) would be to go back to those centres to confirm and add to the collected data, some very interesting results became apparent from the online searches. In the next section, I discuss those findings.

\section{Waves: What is on the Websites and What is Not?}

The initial web search included seven post-secondary institutions, in each case the home institution of a member of the research group for this phase of the study. These were Durham College/UOIT, Guelph University, McMaster University, Mount Allison University, Mount Royal College, University of Waterloo, and University of Windsor.

What became very interesting were the apparent trends in what was readily available, partially available, and apparently not available on ED websites. Table 1 indicates the total number of institutions from our pilot study group $(n=7)$ that fell into each of these three categories.

\section{S.O.S.: Discussion of Findings}

What becomes apparent in examining this chart is that as individual staff we hold a great deal more information about our centres than we post on our websites. That may be intentional, in that websites represent the messages we choose to portray and as such are necessarily distilled. It is worth noting, however, the number of topics where our portrayed information is incomplete or missing, and that only in "name of centre" do we achieve a perfect score.

I suggest that we have three main commu- 


\section{Table 1}

\section{Website Availability of Responses to Questions}

\begin{tabular}{|c|c|c|c|}
\hline $\begin{array}{l}\text { Question } \\
\text { Complied from literature review }\end{array}$ & $\begin{array}{c}\text { Level } 1 \\
\text { Information } \\
\text { available }\end{array}$ & $\begin{array}{c}\text { Level } 2 \\
\text { Information } \\
\text { partially } \\
\text { available or } \\
\text { hard to find* }\end{array}$ & $\begin{array}{l}\text { Level } 3 \\
\text { Information } \\
\text { does not } \\
\text { seem to be } \\
\text { on web }\end{array}$ \\
\hline $\begin{array}{l}\text { 1. Name of unit (including previous names, dates of } \\
\text { change) note not all show historical names. }\end{array}$ & $7^{* *}$ & - & - \\
\hline $\begin{array}{l}\text { 2. History - when established, length of time in current } \\
\text { form. }\end{array}$ & 2 & - & 5 \\
\hline 3. Amalgamated with other units? Now? In past? & 1 & - & 6 \\
\hline $\begin{array}{l}\text { 4. Staff - full-time, part-time, job titles, academic } \\
\text { qualifications? (e.g., degrees). Time in role? }\end{array}$ & 1 & 5 & 1 \\
\hline 5. Role of head of unit (title, position within institution). & 1 & - & 6 \\
\hline 6. Physical location on campus. & 3 & 2 & 2 \\
\hline 7. Role, expected activities. & 3 & 4 & - \\
\hline $\begin{array}{l}\text { 8. Organizational status, reporting lines, links to other } \\
\text { departments? }\end{array}$ & 1 & - & 6 \\
\hline 9. Mission statement? Stated goals? & 5 & 1 & - \\
\hline $\begin{array}{l}\text { 10. Interaction of faculty with centre as 'helpers' (leading } \\
\text { programs, committees, etc). }\end{array}$ & 1 & 2 & 4 \\
\hline $\begin{array}{l}\text { 11. Activities - noting whether any are shared responsibility } \\
\text { with other units. }\end{array}$ & 2 & 3 & 2 \\
\hline $\begin{array}{l}\text { 12. Activities of greatest impact (and how is impact } \\
\text { assessed?). }\end{array}$ & - & - & 7 \\
\hline $\begin{array}{l}\text { 13. Contribute to institutional strategy development on } \\
\text { teaching and learning? In what way? }\end{array}$ & - & 1 & 6 \\
\hline 14. Report to academic community on activities? & - & 1 & 6 \\
\hline 15. Research? Own? Supporting faculty? & - & 1 & 6 \\
\hline 16. E-learning development role. & - & 2 & 5 \\
\hline $\begin{array}{l}\text { 17. Other teaching development related departments at } \\
\text { institution? Collaboration? }\end{array}$ & - & - & 7 \\
\hline 18. Mandatory programs? All voluntary attendance? & - & - & 7 \\
\hline 19. Collect statistics on activities? & - & - & 7 \\
\hline
\end{tabular}

\footnotetext{
* Partly available indicated that not all data provided by the centre was found on their website. ${ }^{* *} \mathrm{n}=7$
} 


\begin{tabular}{|c|c|c|c|}
\hline 20. Funding - sources (e.g., all central, other). & 1 & - & 6 \\
\hline $\begin{array}{l}\text { 21. Institutional climate - teaching and learning highlighted } \\
\text { in overall institutional statement? }\end{array}$ & 4 & 1 & 2 \\
\hline 22. Give awards for teaching and/or related activities? & 2 & 1 & 4 \\
\hline 23. Awards won (3M, other, both internal and external). & 1 & 2 & 4 \\
\hline 24. Grants - do they give them? & 2 & 2 & 3 \\
\hline 25. Grants - do they (or staff) have any? & 1 & - & 6 \\
\hline $\begin{array}{l}\text { 26. Professional development for own staff? (e.g., courses, } \\
\text { conferences, etc). }\end{array}$ & - & 1 & 6 \\
\hline 27. Are learning communities supported? In what? & 1 & - & 6 \\
\hline 28. Sabbatical leaves. & - & - & 7 \\
\hline 29. Travel funds for conferences, meetings. & - & - & 7 \\
\hline 30. How are activities planned? (what offered, when, etc?) & - & - & 7 \\
\hline 31. Primary philosophy re: development. & - & 1 & 6 \\
\hline $\begin{array}{l}\text { 32. Upon what literature do you draw to inform your } \\
\text { practices? }\end{array}$ & - & 1 & 6 \\
\hline 33. Course (credit or not) in university teaching offered? & 3 & 1 & 3 \\
\hline $\begin{array}{l}\text { 34. How does the unit 'build bridges' to gain points of } \\
\text { entry? }\end{array}$ & - & 2 & 5 \\
\hline 35. Policies developed/implemented. & - & 1 & 6 \\
\hline $\begin{array}{l}\text { 36. Innovations promoted by the unit, ways of evaluating } \\
\text { their impact, obstacles to innovations. }\end{array}$ & - & 2 & 5 \\
\hline 37. Committee memberships. & - & - & 7 \\
\hline 38. Research into learning and teaching undertaken. & - & - & 7 \\
\hline 39. How unit's work is evaluated? & - & - & 7 \\
\hline
\end{tabular}

nities to whom we communicate: faculty, staff, and students within our own institutions, administrators within our own institutions, and other ED centres. I acknowledge that there may be other groups, but I will focus in this section on considerations for these three.

\section{Institution: Faculty, staff, students}

Arguably, our websites exist to inform our academic communities what we do and how we do that work. Regrettably, the evidence suggests we may not be achieving that aim. For example, in Q6 (physical location on campus), Q7, and Q11 (our activities) information is remarkably incomplete. Certainly centres may argue that much of this information is available online, but I suggest it is primarily available to those who already know what they are looking for and where to look. Could someone who does not know your campus find your centre based on the website information?

\section{Institution: Administrators}

While administrators need to know about our specific activities and mission and goals, they also need 
to know about the impact our activities have, and they need easy access to this information when making funding decisions. For example, as a group, we could be doing a better job of communicating how we assess the impact of our work (Q12), and policies and innovations developed (Q35 \& Q36). In tough economic times, it is troublesome that we miss the opportunity to educate administrators about what we do, and we fall short on communicating statistics about our work (Q19). We could use our websites powerfully to our advantage: articulating a response to how we are evaluated (Q39) could in fact help us guide this process.

\section{Other ED centres}

I believe we have a responsibility to provide information that will be useful to our discipline colleagues. A recent search of 12 Canadian universities to compile scholarship of teaching and learning (SoTL) grants and amounts showed that very little of this information was available on centre websites, much was difficult to find, and in many cases website information was out of date. It is in our own interest that we provide information that we and others will find useful.

I wish to make a special plea for communicating SoTL information on our websites. This is a powerful and growing area of inquiry in post-secondary settings: not communicating our work ultimately can inhibit growth in this area. In addition, in research-intensive settings, SoTL can open conversations. There is also much to be gained by making explicit our support for research in teaching and learning (Q38) and on what literature we draw to inform our work (Q32).

\section{Lifejackets: Strategies for Website Improvement}

These are but a few examples where our websites could benefit from greater clarity. Within our group and at conference presentations we have begun to discuss strategies for better communicating ED work via our websites. Suggestions have included:

- post year end reports;

- organize the website by services available rather than by staff;

- organize the website as responses to FAQ;

- include achievements of people we have worked with to show impact of our work on others);

- consult other sites for exemplars;

- build websites for others (use post-its with what we want on site, arrange as a template, ask those outside the centre to re-arrange the template); and,

- given the importance of communication and how much time is involved in updating sites, hire someone to manage it.

\section{Message in a Bottle: Codicil and Conclusions}

This paper may seem to present a negative view of ED centre websites, and that is not our intention. The compiled questions do not necessarily represent areas around which centres have designed their websites. In addition, while the trends in the data are interesting and may serve to inform ED centres undertaking website and strategic planning review, clearly there is a need to add the additional data we have collected from 35 other centres to see if these patterns hold. We will of course return to our primary study purpose of compiling responses to all questions from as many Canadian ED centres as we can and will be posting a searchable database to the EDC website. A spreadsheet can be compiled to any who request it.

As website renewal is an ongoing process, we also recognize our chart is likely already out of date and perhaps the ship has already sailed. However, the trends it represents are compelling and will hopefully encourage centres to consider areas that represent opportunities for charting a course to making our work more explicit. 


\section{References}

Carusetta, E. \& Cranton, P. (2005). Nurturing authenticity through faculty development. Journal of Faculty Development, 20(2), 79-86.

Cox, M. (2002). Proven faculty development tools that foster the scholarship of teaching in faculty learning communities. To Improve the Academy: Resources for Faculty, Instructional, and Organizational Development, 21, 109-142.

Donald, J.G. (1986). An inventory of programs, courses, and other forms of pedagogical training of higher education personnel in Canada: Report to the European Centre for Higher Education. Montreal, PQ: Centre for University Teaching and Learning, McGill University, Montreal, QC.

Elrick, M. (1990). Improving instruction in universities: A case study of the Ontario Universities Program for Instructional Development (OUPID). The Canadian Journal of Higher Education, 20(2), 61-79.

Gosling, D. (2001). Educational development units in the UK: What are they doing five years on? The International Journal of Academic Development, 6(1), 74-90.

Gosling, D. (2006). Report of the heads of educational development group: Survey of educational development units in the UK 2006. Heads of Educational Development Group.

Konrad, A.G. (1983). Faculty development practices in Canadian universities. Canadian Journal of Higher Education, XIII(2), 13 - 25.

Kreaden, M. (2001). Mandatory faculty development works. To Improve the Academy: Resources for Faculty, Instructional, and Organizational Development, 20, 107-127.

Kreber, C. \& Brook, P. (2001). Impact evaluation of educational development programmes. Inter- national Journal for Academic Development, 6(2), 96-108.

Lawlor, P.A. \& King, K.P. (2003). Best practices in faculty development in North American higher education: Distinctions and dilemmas. Journal of Faculty Development, 19(1), 29-36.

Lewis, K.G. (1996). Faculty development in the United States: A brief history. International Journal for Academic Development, 1(2), 2633.

Mindorff, D., Ratkovic, S., \& Babady-Bila, F. (2004). Teaching and learning in higher education: An overview of centres for teaching and learning in Canadian universities. [CD]. Brock University Faculty of Education, St. Catharines, ON.

Scarfe, A. (2004). An historical overview of instructional development in Canadian Higher Education. Teaching and Learning Bridges, 2(4), 2-7. University of Saskatchewan, Saskatoon, SK.

Wilcox, S. (1997). Learning from our past: The history of educational development in Canadian universities. Occasional Papers in Higher Education, 8. Centre for Higher Education Research and Development, The University of Manitoba and The Society for Teaching and Learning in Higher Education.

Wilcox, S. (1998). Claiming to understand educational development. In M.L. Hamilton \& S. Pinnegar (Eds.), Reconceptualizing teaching practice: Self-study in higher education (pp. 6776). New York: Routledge.

\section{Biography}

Nicola Simmons is the Research and Evaluation Consultant at the Centre for Teaching Excellence (CTE) at the University of Waterloo. Her scholarly interests include educational development, scholarship of teaching and learning, and reflective practice. 